\title{
Performance Appraisal of Select Nations in Mitigation of COVID-19 Pandemic using Entropy based TOPSIS Method
}

\author{
Avaliação de desempenho de nações selecionadas na mitigação \\ de pandemia de COVID-19 usando método TOPSIS \\ baseado em entropia
}

${ }^{1}$ Department of

Management, Humanities \& Social Sciences, National Institute of Technology. 799046 Agartala Tripura India.dnecon@gmail.com

\begin{abstract}
The present study was an effort to assess the mitigation interventions carried out, so far, by the nations to fight the pandemic COVID-19. The novelty of the study was that it had considered the issue of pandemic mitigation strategy as a decision making problem. The performances of the twenty nations were to be ranked. The problem considered in the study was essentially a MultiCriteria Decision Analysis (MCDA) problem. The available alternatives were the 20 countries and the 8 traits were the criteria. The Technique of Order Preference Similarity to the Ideal Solution (TOPSIS) was used in the present study. The study used Entropy method for assignment of weights to all the criteria. The performance score obtained in respect of the countries considered in the study and the corresponding ranks indicated the relative performances of the countries in their efforts to mitigate the COVID-19 pandemic. The results show that New Zealand is the best performing country and India is the worst one. Brazil ranked $17^{\text {th }}$, while the rank of UK was 15. The performance of the USA stood at $18^{\text {th }}$ position.

Key words Coronavirus, Multi-Criteria Decision Analysis, Positive Ideal Solution, Beneficial and Non-Beneficial Criteria, Performance Score
\end{abstract}

Resumo O presente estudo foi um esforço para avaliar as intervenções de mitigação realizadas, até o momento, pelas nações para combater a pandemia COVID-19. A novidade do estudo é que considerou a questão da estratégia de mitigação da pandemia como um problema de tomada de decisão. As performances das vinte nações deveriam ser classificadas. O problema considerado no estudo era essencialmente um problema de Análise de Decisão Multi-Critério (MCDA). As alternativas disponiveis eram os 20 países e as 8 características eram os critérios. A Técnica de Similaridade de Preferência de Pedido com a Solução Ideal (TOPSIS) foi utilizada no presente estudo. O estudo utilizou o método da Entropia para atribuição de pesos a todos os critérios. A pontuação de desempenho obtida em relação aos países considerados no estudo e as classificações correspondentes indicaram os desempenhos relativos dos países em seus esforços para mitigar a pandemia COVID-19. Os resultados mostram que a Nova Zelândia é o país com melhor desempenho e a Índia o pior. O Brasil ficou em $17^{\circ}$, enquanto o Reino Unido ficou em 15. O desempenho dos EUA ficou na $18^{a}$ posição.

Palavras-chave Coronavirus, Análise de Decisão Multicritério, Solução Ideal Positiva, Critérios Benéficos e Não Benéficos, Pontuação de desempenho 


\section{Introduction}

The worst ever pandemic the world faced in a century or so that had put the very existence of the civilization on earth at stake was COVID-19. The three major characteristics that made the outbreak a deadly one were the pace with which the infection spread; the intensity of the infection and the societal and economic disruption it caused ${ }^{1}$.

The World Health Organization (WHO) mentioned about three methods of influenza containment: antiviral, vaccine and non-clinical. The non-clinical method involved identification of infected people followed by their isolation; tracing persons who came in contact with the infected ones and ensuring their quarantine; restrictions on travel; temporary closing down of schools, offices etc along with full or partial lockdown ${ }^{2}$. Ferguson et al. ${ }^{3}$ found that within the category of the non-clinical mitigation efforts, restrictions on both internal and international travel did not prove very fruitful ${ }^{3}$. However, the probability of the spread of infection increased many folds with movement of people with pre-symptomatic cases from one place to the other coupled with the absence of public health interventions in required scale ${ }^{4}$. WHO in one of its situation reports related to COVID-19 referred to China's responses and actions that proved effective to contain the spread of the disease ${ }^{5}$. Anderson et al. ${ }^{6}$ made a special mention about the severity and also the highest level of stringency with which China tried to contain the pandemic ${ }^{6}$.

With this backdrop, the present study was an effort to assess the mitigation interventions carried out, so far, by the nations to fight the pandemic called COVID-19. This assessment was based on evaluating the performances of the nations with respect to select criteria. The study had considered 20 nations for the purpose. The selected countries were: Australia, Brazil, Canada, Ethiopia, Germany, India, Iran, Italy, Japan, Kazakhstan, New Zealand, Norway, Qatar, Russia, Saudi Arabia, Singapore, South Korea, Spain, United Kingdom and the United States.

The criteria selected for the performance evaluation were based on the importance attached in literature to such criteria. Given, the COVID-19 pandemic was only a few months old, data on all the desired criteria to carry out a meaningful study were not available for obvious reasons. This constraint accompanied the study throughout. Depending on the availability of data and its relevance to the performance eval- uation of the nations, the study had considered eight criteria, which were as follows:

1. Tests per million population: Months back on $16^{\text {th }}$ March 2020, Mr. Bruce Aylward, the Assistant Director General of World Health Organization mentioned that coronavirus could be resisted from spreading through effective quarantine, which was only possible through extensive tests of COVID-197.

2. Death per million population: The count of deaths per million population, as pointed out by the President of Public Health Foundation of India Mr. K. Srinath Reddy, emerged as a good indicator of containment of contagion. Many countries in Europe had also used this criterion to assess whether to ease the lockdown, when the partial or full lockdown was enforced to gain control over the spread of infection'.

3. Case-Fatality Rate: The Case-Fatality Rate referred to the severity of the pandemic, besides identifying at-risk populations. The present study had used the number of confirmed cases as the base and the Case-Fatality Rate was calculated as a ratio of total number of deaths and total number of confirmed cases, was used ${ }^{9}$.

4. Tests per confirmed case: For comparative assessment with respect to some standard base, the use of the number of tests per confirmed case as a reliable estimate of the infected people had gained ground. The country that had a very few tests against each confirmed case was identified as the one not carrying out the tests sufficiently ${ }^{10}$.

5. Hospital Beds per thousand population: The availability of hospital beds showed the preparedness of the nations besides their abilities of timely resource mobilization for the pandemic mitigation. For instance, New Zealand commenced its preparation as early as in February 2020. The country had started, since then, preparing the hospitals for COVID infected patients ${ }^{11}$. The number of hospital beds per thousand population was one of the criteria to assess the performances of the nations to fight the pandemic. However, the lack of relevant data, especially on the availability of intensive care beds, prevented us from considering the availability of the number of intensive care beds and the number of nursery beds separately.

6. Highest level of stringency imposed by the government: Governments' responses played a crucial role in mitigating the crisis of COVID-19. The Oxford COVID-19 Government Response Tracker (OxCGRT) had formulated four common indices reporting a number between 1 and 100 to highlight the government's responses to 
various issues pertaining to the pandemic. One of these four indices was the stringency index, accounting for the strictness with which the lockdown had been enforced ${ }^{12}$. Since lockdown was used to contain the disease, at least during the early stage of the pandemic, the highest levels of stringencies could be considered as a criterion to assess the performances of the countries to counter the spread of the disease.

7. People's Confidence on governments' actions and responses: The success of the governments' policies depended on the citizens' confidence on governments' actions. A majority of the populations across the world were in favor of strong government actions to control the pandemic. But the section of population from the low income group, facing the hardship due to the financial uncertainty and also due to their inability to abide by the social distancing norm, were not found supportive of the governments' actions ${ }^{13}$. Considering all this, the present study had taken into account the people's confidence on the governments' actions and responses as one of the criteria to assess the performances of the countries to mitigate the pandemic. The perceptions about the governments' actions and responses were arranged in a twenty point scale with the country having the worst level of its citizens' confidence marked 1 .

8. Size of populations: While on the one side, a relatively smaller population could make the government's administrative jobs, like enforcing the measures to control the spread of the infections with adequate follow-up actions along with monitoring for its compliance, easier; on the other, the probability of large scale public gathering could also be avoided. For a comparative analysis of the countries, the size of the population was, thus, an indispensable criterion.

\section{Methodology}

The novelty of the present study lied in the fact that it considered the issue of pandemic mitigation strategy as a decision making problem. In this study, the performances of 20 nations were to be ranked. The ranking was done on the basis of 8 criteria. Thus, the problem considered in the study essentially needed a Multi-Criteria Decision Analysis (MCDA) approach. In fact, MCDA led to making preference decisions that involved evaluations, prioritizations and selection of the alternatives, characterized by multiple and often conflicting traits ${ }^{14}$. A number of methods were available in literature for applying the MCDA approach. The Technique of Order Preference Similarity to the Ideal Solution (TOPSIS), one of the widely used approaches, was used in the present study. TOPSIS was often used for performance evaluation. Yoon and Hwang ${ }^{15}$ developed the Technique for Order Preference by Similarity to Ideal Solution (TOPSIS) to identify a solution from a finite set of points. Linear weighting technique was applied in this method which also ensured that the chosen alternative had the shortest distance from the positive ideal solution and simultaneously lied farthest from the negative-ideal solution. TOPSIS was built on the assumption that each criterion in the decision matrix could take either monotonically increasing or monotonically decreasing utility. Accordingly, for the beneficial criteria i.e., for the criteria for which higher values were preferred, the larger the criterion outcomes were, the greater were the preferences attached. Similarly, in case of the non-beneficial or cost criteria, the higher the values of the criteria were, the lesser would be the preferences for such criteria. TOPSIS also required the quantification of non-numerical values using the proper scaling technique ${ }^{15,16}$. Bulgurku ${ }^{17}$ had used TOPSIS as a multi-decision making model to measure and compare the financial performances of thirteen technology firms operating in Istanbul Stock Exchange. The study assessed the firms in terms of ten financial ratios ${ }^{17}$. Yildirim and Yildirim ${ }^{18}$ had used Grey TOPSIS method to evaluate and rank the competitive performance of eight developing nations ${ }^{18}$. MASCA (2017) had used TOPSIS method for economic performance evaluation of twenty eight countries of European Union. The study considered six macroeconomic indicators for performance evaluation ${ }^{19}$. Kilıç and $\mathrm{Ta} \mathrm{an}^{20}$ had made use of the TOPSIS method for performance evaluation of the sustainability indicators related to production in case of two different multi-decision making problems in a sustainability conscious manufacturing company ${ }^{20}$.

The analysis of TOPSIS used some pre-assigned weights to all the criteria involved. Different methods were there in the literature for assigning weights. Shannon's entropy method was one of such methods ${ }^{21}$. The concept of entropy was first developed by Shanon and Weaver ${ }^{22}$ in 1947. Research on exploring the applications of Shanon and Weaver entropy eventually could find its use in decision analysis. The entropy was used to compute the weights of the criteria included in MCDA. Yue ${ }^{23}$ had used entropy based TOPSIS approach to model group decision mak- 
ing. Kaynak et al. ${ }^{24}$ in their study compared the innovation performance of four EU candidate countries. The study had used the entropy method to find the relative weights of the variables. Then the TOPSIS approach was used for prioritization of the countries with respect to their innovation performance ${ }^{24}$.

The present study used Entropy method for weight assignment. Thus, it was entropy based TOPSIS approach applied to solve the multi-criteria decision making problem considered in the paper.

\section{Materials and methods}

The study was based on the country wise data available till August 3, 2020. As noted earlier, the analysis of the performances of nations in mitigation of COVID-19 had been challenging due to the lack of reliable data on all relevant criteria. In spite of this, efforts had been made to collect data from a wide variety of sources. The paper used the data available in GitHub ${ }^{25}$, Our World in data ${ }^{26-28}$, Statista ${ }^{29-31}$, Dalia ${ }^{32}$ and World Bank ${ }^{33}$ to get country-wise data on eight criteria mentioned above.

We considered data, available by August 3, 2020, for all the criteria except for the criterion Peoples' Confidence on governments' Actions and Responses. For some countries and for some criteria, data till August 3 were not available. In such cases data available till the nearest date earliest by July 27, 2020 - had been used. The data on Peoples' Confidence on governments' Actions and Responses was collected online from Dalia dated 30.03.2020. People's level of confidence was decided by their perception on whether government had done too little. The country with the highest proportion of this perception was termed as the worst performer and hence was assigned with number 1 . The Size of Population, however, remained the same for obvious reason during the entire study period and also till the point of time when the data was collected in October 2020.

The problem of heterogeneity in data could be attributed to the varied sources from which the data had been collected. But such heterogeneity in data did not affect the analysis as it had been observed that the data on any particular parameter did not abruptly change over very short run. The data analysis part of the paper had two major sections. The first section was to assign weights to all of the eight criteria using the En- tropy method. The second section of data analysis was to use the TOPSIS method of multi criteria decision analysis to judge the performances of the 20 nations considered in the study. The entire computations involved in Entropy and TOPSIS had been carried out using MS Excel software.

\section{Results}

The collected data were put in a matrix called Decision Matrix (Chart 1). The first step of Entropy method of weight determination was normalization of the decision matrix.

rij (data probability distribution) was calculated as described below:

$$
\mathrm{rij}=\frac{\mathrm{Xij}}{\sum_{1=1}^{20} \mathrm{Xij}},
$$

$\mathrm{i}=$ countries; $j=$ criteria; $X_{\mathrm{ij}}=$ element of ith row (country) and jth column (criterion) and $j=1$, $2, \ldots ., 8$

The second step was to compute Entropy $\left(e_{j}\right)$. The entropy value of the criteria (occurrence probability, severity, and vulnerability; ej) was calculated as below:

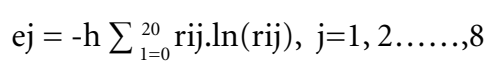

Also, $\mathrm{h}$ was a fixed value in which $\mathrm{m}$ was the number of countries and calculated by the following relation:

$$
\begin{aligned}
& \mathrm{h}=\frac{1}{\ln (\mathrm{m})} ; \mathrm{m}=\text { number of countries=20. } \\
& \text { So, } \mathrm{h}=\frac{1}{\ln (20)}
\end{aligned}
$$

The third step was to compute weight vector (Chart 2). The value of non-reliance or diversification (1-wj) was calculated. Non-reliance or diversification (1-wj) obtained from data for criterion $\mathrm{j}$ indicated to what extent the useful information was placed at the disposal of the decision maker for decision making ${ }^{34}$. The value of weight vector wj was obtained in the following way:

$$
\begin{aligned}
& w j=\frac{1-e j}{\sum_{j=1}^{7}(1-e j)} ; \\
& (1-e j)=\text { Degree of Diversification }
\end{aligned}
$$

Thus, it could be seen that the most important criterion in COVID-19 mitigation came out to be size of populations followed by the number of tests per confirmed case as the second most important criterion. The weights assigned 
Chart 1. Decision Matrix.

\begin{tabular}{|c|c|c|c|c|c|c|c|c|}
\hline \multirow[b]{2}{*}{$\begin{array}{c}\text { Countries } \\
\text { (Alternatives) }\end{array}$} & \multicolumn{8}{|c|}{ Criteria } \\
\hline & $\begin{array}{c}\text { Tests per } \\
\text { million } \\
\text { population }\end{array}$ & $\begin{array}{l}\text { Death per } \\
\text { million } \\
\text { population }\end{array}$ & $\begin{array}{c}\text { Case- } \\
\text { Fatality } \\
\text { Rate }\end{array}$ & $\begin{array}{l}\text { Tests per } \\
\text { confirmed } \\
\text { case }\end{array}$ & $\begin{array}{l}\text { Hospital } \\
\text { beds per } \\
\text { thousand } \\
\text { population }\end{array}$ & $\begin{array}{l}\text { Highest } \\
\text { level of } \\
\text { Stringency }\end{array}$ & $\begin{array}{l}\text { Confidence on } \\
\text { governments' } \\
\text { responses and } \\
\text { actions (Rank } \\
\text { with worst }=1 \text { ) }\end{array}$ & $\begin{array}{c}\text { Size of } \\
\text { Population } \\
\text { (in Billion) }\end{array}$ \\
\hline Australia & 1720.4 & 9.28 & 1.24 & 244.76 & 3.84 & 75.93 & 4 & 0.025 \\
\hline Brazil & 61573 & 451.93 & 3.44 & 4.76 & 2.2 & 81.02 & 5 & 0.21 \\
\hline Canada & 109698 & 242.72 & 7.56 & 35.75 & 2.5 & 74.54 & 7 & 0.04 \\
\hline Ethiopia & 14 & 3.08 & 1.74 & 0.08 & 0.3 & 80.56 & 16 & 0.11 \\
\hline Germany & 95529 & 110.39 & 4.32 & 37.88 & 8 & 76.85 & 9 & 0.0831 \\
\hline India & 14627 & 28.79 & 2.1 & 11.2 & 0.53 & 100 & 14 & 1.37 \\
\hline Iran & 29432 & 212.77 & 5.58 & 8.21 & 1.5 & 59.26 & 3 & 0.829 \\
\hline Italy & 114415 & 581.92 & 14.17 & 16.66 & 3.18 & 93.52 & 10 & 0.06 \\
\hline Japan & 87 & 8.05 & 2.54 & 32.01 & 13.05 & 47.22 & 2 & 0.13 \\
\hline Kazakhstan & 110636 & 43.39 & 0.85 & 22.15 & 6.7 & 89.35 & 19 & 0.02 \\
\hline New Zealand & 982.5 & 4.5 & 1.4 & 389.29 & 2.61 & 96.3 & 18 & 0.0049 \\
\hline Norway & 802.4 & 48.17 & 2.74 & 47.24 & 3.6 & 79.63 & 17 & 0.0053 \\
\hline Qatar & 178266 & 63.63 & 0.16 & 4.53 & 1.2 & 86.11 & 20 & 0.003 \\
\hline Russia & 197295 & 98.17 & 1.66 & 34.32 & 8.05 & 87.04 & 11 & 0.14 \\
\hline Saudi Arabia & 98461 & 87.51 & 1.05 & 12.43 & 2.7 & 94.44 & 15 & 0.034 \\
\hline Singapore & 1053.5 & 4.79 & 0.5 & 0.11 & 2.4 & 85.19 & 13 & 0.006 \\
\hline South Korea & 306.4 & 5.83 & 2.09 & 108.93 & 12.27 & 82.41 & 12 & 0.052 \\
\hline Spain & 142834 & 609.37 & 9.58 & 21.82186 & 2.97 & 85.19 & 1 & 0.047 \\
\hline UK & 242929 & 695 & 15.12 & 32.3 & 2.54 & 75.93 & 8 & 0.07 \\
\hline USA & 180977 & 474.45 & 3.3 & 12.33 & 2.77 & 72.69 & 6 & 0.33 \\
\hline
\end{tabular}

Sources: github; our world in data; statista; Dalia; World Bank.

were $24.35 \%$ and $22.19 \%$ respectively. The third most important criterion was the total number of deaths per million population with weight of $16.84 \%$. The fourth important criterion was found to be the number of tests per million population with weight of $13.78 \%$. The fifth important criterion was Case-Fatality Rate with weight of $10.82 \%$. Availability of the number of hospital beds per thousand population was the sixth important criterion with weight of $7.59 \%$. The confidence of people on the governments' actions and responses to COVID-19 crisis and the highest level of stringency adopted by the governments to restrict the spread of pandemic were the last two important criteria with assigned weights found to be very low $4.15 \%$ and $0.29 \%$ respectively.

The first step in TOPSIS was to normalize the decision matrix given in Chart 1 :

$$
X i j=\frac{X i j}{\sqrt{\sum_{1=1}^{20} x^{2} i j}} \quad, i=\text { countries; } j=j \text { th cri- }
$$

terion; $\mathrm{X}_{\mathrm{ij}}=$ element of ith row (country) and jth column

The second step was to calculate Weighted Normalized Matrix (Chart 3). This was done by multiplying the weights computed for each criterion using Entropy method with the normalized elements of the decision matrix: $V_{i j}=\alpha \bar{X}_{i j}{ }^{*} W_{j}$

The third step was to find ideal best $\mathrm{V}_{j}^{+}$and ideal worst $\mathrm{V}_{-}^{-}$of each criterion (Chart 4). The fourth step involved calculating Euclidian distance of the elements of the weighted normalized matrix from the ideal best. This was calculated for each of the 20 nations considered in the study:

$$
\mathrm{S}_{\mathrm{i}}^{+}=\left[\sum_{\mathrm{j}=1}^{7}\left(\mathrm{Vij}-\mathrm{Vj}^{+}\right)^{2}\right]^{0.5}
$$

In the same way, the fifth step involved calculation of Euclidian distance of the elements of the weighted normalized matrix from the ideal worst. This was also calculated for each nation.

$$
S_{i}^{-}=\left[\sum_{j=1}^{7}\left(V_{i j}-V_{j}^{-}\right)^{2}\right]^{0.5}
$$


Chart 2. Entropy and Weight Vectors for the criteria.

\begin{tabular}{|l|c|c|c|c|c|c|c|c|}
\hline \multicolumn{1}{|c|}{ Criteria } & $\begin{array}{c}\text { Tests per } \\
\text { million } \\
\text { population }\end{array}$ & $\begin{array}{c}\text { Death per } \\
\text { million } \\
\text { population }\end{array}$ & $\begin{array}{c}\text { Case- } \\
\text { Fatality } \\
\text { Rate }\end{array}$ & $\begin{array}{c}\text { Tests per } \\
\text { confirmed } \\
\text { case }\end{array}$ & $\begin{array}{c}\text { Hospital } \\
\text { beds per } \\
\text { thousand } \\
\text { population }\end{array}$ & $\begin{array}{c}\text { Highest } \\
\text { level of } \\
\text { Stringency }\end{array}$ & $\begin{array}{c}\text { Confidence on } \\
\text { governments' } \\
\text { responses and } \\
\text { actions (Rank } \\
\text { with worst=1) }\end{array}$ & $\begin{array}{c}\text { Size of } \\
\text { Population } \\
\text { (in Billion) }\end{array}$ \\
\hline Entropy $\left(\mathrm{e}_{\mathrm{j}}\right)$ & 0.8108 & 0.7688 & 0.8515 & 0.6954 & 0.8958 & 0.9961 & 0.9431 & 0.6657 \\
\hline Weight Vector & 0.1378 & 0.1684 & 0.1082 & 0.2219 & 0.0759 & 0.0029 & 0.0415 & 0.2435 \\
\hline
\end{tabular}

Chart 3. Weighted Normalized Matrix.

\begin{tabular}{|l|c|c|c|c|c|c|c|c|}
\hline & \multicolumn{7}{|c|}{ Tests per } \\
Countries & $\begin{array}{c}\text { million } \\
\text { population }\end{array}$ & $\begin{array}{c}\text { Death per } \\
\text { million } \\
\text { population }\end{array}$ & $\begin{array}{c}\text { Case- } \\
\text { Fatality } \\
\text { Rate }\end{array}$ & $\begin{array}{c}\text { Tests per } \\
\text { confirmed } \\
\text { case }\end{array}$ & $\begin{array}{c}\text { Hospital } \\
\text { beds per } \\
\text { thousand } \\
\text { population }\end{array}$ & $\begin{array}{c}\text { Highest } \\
\text { level of } \\
\text { Stringency }\end{array}$ & $\begin{array}{c}\text { Confidence on } \\
\text { governments' } \\
\text { responses and } \\
\text { actions (Rank } \\
\text { with worst=1) }\end{array}$ & $\begin{array}{c}\text { Size of } \\
\text { Population } \\
\text { (in Billion) }\end{array}$ \\
\hline Australia & 0.0006 & 0.0016 & 0.0068 & 0.1486 & 0.0159 & 0.0008 & 0.0041 & 0.0036 \\
\hline Brazil & 0.0227 & 0.0757 & 0.0188 & 0.0029 & 0.0091 & 0.0008 & 0.0051 & 0.0306 \\
\hline Canada & 0.0405 & 0.0407 & 0.0413 & 0.0217 & 0.0103 & 0.0008 & 0.0072 & 0.0058 \\
\hline Ethiopia & 0.0000 & 0.0005 & 0.0095 & 0.0000 & 0.0012 & 0.0008 & 0.0164 & 0.0160 \\
\hline Germany & 0.0352 & 0.0185 & 0.0236 & 0.0230 & 0.0330 & 0.0008 & 0.0092 & 0.0121 \\
\hline India & 0.0054 & 0.0048 & 0.0115 & 0.0068 & 0.0022 & 0.0010 & 0.0143 & 0.1997 \\
\hline Iran & 0.0109 & 0.0356 & 0.0305 & 0.0050 & 0.0062 & 0.0006 & 0.0031 & 0.1209 \\
\hline Italy & 0.0422 & 0.0975 & 0.0774 & 0.0101 & 0.0131 & 0.0010 & 0.0102 & 0.0087 \\
\hline Japan & 0.0000 & 0.0013 & 0.0139 & 0.0194 & 0.0539 & 0.0005 & 0.0020 & 0.0190 \\
\hline Kazakhstan & 0.0408 & 0.0073 & 0.0046 & 0.0135 & 0.0277 & 0.0009 & 0.0194 & 0.0029 \\
\hline New Zealand & 0.0004 & 0.0008 & 0.0076 & 0.2364 & 0.0108 & 0.0010 & 0.0184 & 0.0007 \\
\hline Norway & 0.0003 & 0.0081 & 0.0150 & 0.0287 & 0.0149 & 0.0008 & 0.0174 & 0.0008 \\
\hline Qatar & 0.0658 & 0.0107 & 0.0009 & 0.0028 & 0.0050 & 0.0009 & 0.0205 & 0.0004 \\
\hline Russia & 0.0728 & 0.0164 & 0.0091 & 0.0208 & 0.0332 & 0.0009 & 0.0113 & 0.0204 \\
\hline Saudi Arabia & 0.0363 & 0.0147 & 0.0057 & 0.0075 & 0.0111 & 0.0010 & 0.0153 & 0.0050 \\
\hline Singapore & 0.0004 & 0.0008 & 0.0027 & 0.0001 & 0.0099 & 0.0009 & 0.0133 & 0.0009 \\
\hline South Korea & 0.0001 & 0.0010 & 0.0114 & 0.0661 & 0.0507 & 0.0009 & 0.0123 & 0.0076 \\
\hline Spain & 0.0527 & 0.1021 & 0.0523 & 0.0133 & 0.0123 & 0.0009 & 0.0010 & 0.0069 \\
\hline UK & 0.0896 & 0.1164 & 0.0826 & 0.0196 & 0.0105 & 0.0008 & 0.0082 & 0.0102 \\
\hline USA & 0.0668 & 0.0795 & 0.0180 & 0.0075 & 0.0114 & 0.0008 & 0.0061 & 0.0481 \\
\hline
\end{tabular}

Chart 4. Ideal Best and Ideal Worst of Criteria.

\begin{tabular}{|l|c|c|c|c|c|c|c|c|}
\hline Criteria & $\begin{array}{c}\text { Tests per } \\
\text { million } \\
\text { population }\end{array}$ & $\begin{array}{c}\text { Death per } \\
\text { million } \\
\text { population }\end{array}$ & $\begin{array}{c}\text { Case- } \\
\text { Fatality } \\
\text { Rate }\end{array}$ & $\begin{array}{c}\text { Tests per } \\
\text { confirmed } \\
\text { case }\end{array}$ & $\begin{array}{c}\text { Hospital } \\
\text { beds per } \\
\text { thousand } \\
\text { population }\end{array}$ & $\begin{array}{c}\text { Highest } \\
\text { level of } \\
\text { Stringency }\end{array}$ & $\begin{array}{c}\text { Confidence on } \\
\text { governments } \\
\text { responses and } \\
\text { actions (Rank } \\
\text { with worst=1) }\end{array}$ & $\begin{array}{c}\text { Size of } \\
\text { Population } \\
\text { (in Billion) }\end{array}$ \\
\hline Ideal Best & 0.0678 & 0.0004 & 0.0007 & 0.1788 & 0.0408 & 0.0008 & 0.0155 & 0.0004 \\
\hline Ideal Worst & 0.0000 & 0.0881 & 0.0625 & 0.0000 & 0.0009 & 0.0004 & 0.0008 & 0.1997 \\
\hline
\end{tabular}


Chart 5. Performance Scores of Countries.

\begin{tabular}{|l|c|c|c|c|}
\hline $\begin{array}{c}\text { Countries } \\
\text { (Alternatives) }\end{array}$ & $\begin{array}{c}\text { Euclidian distance } \\
\text { from Ideal Best }\left(\mathbf{S}^{+}\right)\end{array}$ & $\begin{array}{c}\text { Euclidian distance from } \\
\text { Ideal Worst }\left(\mathbf{S}^{-}\right)\end{array}$ & $\begin{array}{c}\text { Performance Score } \\
\left(\mathbf{P}_{\mathrm{i}}\right)\end{array}$ & Rank \\
\hline Australia & 0.0998 & 0.2491 & 0.7141 & 2 \\
\hline Brazil & 0.1985 & 0.1795 & 0.4749 & 17 \\
\hline Canada & 0.1756 & 0.2077 & 0.5418 & 10 \\
\hline Ethiopia & 0.1961 & 0.2112 & 0.5186 & 13 \\
\hline Germany & 0.1694 & 0.2105 & 0.5541 & 8 \\
\hline India & 0.2749 & 0.1009 & 0.2684 & 20 \\
\hline Iran & 0.2267 & 0.1077 & 0.3222 & 19 \\
\hline Italy & 0.2010 & 0.1947 & 0.4920 & 16 \\
\hline Japan & 0.1794 & 0.2116 & 0.5412 & 11 \\
\hline Kazakhstan & 0.1739 & 0.2251 & 0.5642 & 4 \\
\hline New Zealand & 0.0752 & 0.2875 & 0.7928 & 5 \\
\hline Norway & 0.1740 & 0.2228 & 0.5615 & 7 \\
\hline Qatar & 0.1817 & 0.2294 & 0.5581 & 6 \\
\hline Russia & 0.1662 & 0.2119 & 0.5604 & 9 \\
\hline Saudi Arabia & 0.1811 & 0.2196 & 0.5479 & 12 \\
\hline Singapore & 0.1941 & 0.2258 & 0.5378 & 3 \\
\hline South Korea & 0.1461 & 0.2268 & 0.6082 & 14 \\
\hline Spain & 0.1948 & 0.1990 & 0.5053 & 15 \\
\hline UK & 0.1992 & 0.2020 & 0.5035 & 0.3264 \\
\hline USA & 0.1935 & 0.0938 & & 18 \\
\hline
\end{tabular}

The next step was to compute the performance score $\mathrm{P}_{\mathrm{i}}$ in respect of every nation:

$\mathrm{P}_{\mathrm{i}}=\mathrm{S}_{\mathrm{i}}^{-} /\left(\mathrm{S}_{\mathrm{i}}^{-}+\mathrm{S}_{\mathrm{i}}^{+}\right)$

Finally, the performance scores were ranked to judge the relative performances of each of the countries (Chart 5).

The performance scores and the corresponding ranks indicated the relative performances of the countries to mitigate the COVID-19 pandemic. The results showed that New Zealand was the best performing country, followed by Australia. The third best country was South Korea, while Kazakhstan came out to be the fourth best country. Norway had been the fifth best performing nation. In the same way, taking stock of the five worst performing nations revealed that India was worst one to mitigate the crisis with a performance rank of 20. Iran was the second worst one while the USA was the third worst performer. Brazil and Italy were the fourth and fifth worst performing nations. Among the other countries, the relative performances could be well understood with the performances of Russia with rank 6; Canada with 10; Germany with 8; the African nation Ethiopia with 13; Spain with 14; Singapore with 12; Saudi Arabia with 9; Japan with 11; UK with 15 and Qatar with rank 7.

\section{Discussion}

The rankings of the nations indicating their relative performances in COVID-19 mitigation were the outcome of the conjugate impact of the relative importance of the criteria and the performances of the nations in respect of these criteria. For instance, in case of UK, in spite of being the best performer in tests per million populations and above average performance in tests per confirmed case, the country was found to be the worst performer both in cases of death per million population and the Case-Fatality Rate. With below average performance in rest of the criteria, the country's overall rank was less impressive and stood at 15.

In another instance, Italy with very close to being the worst performer both in death per million population and the Case-Fatality Rate had an overall rank of 16 . This was in spite of its above average performance in tests per million population; just below the average performance in tests per confirmed case and reasonably better performances in availability of hospital beds, in stringency index and peoples' confidence on government's actions.

When we compared the findings of the study with that of the reality, the study proved its worth. 
According to WHO, New Zealand got early success in controlling infection due to its very early action in response to the pandemic crisis. New Zealand achieved its "crushing the curve" success with its approach to mitigate the crisis through extensive and rapid testing, followed by contact tracing and isolation. New Zealand was very particular in adhering to the public health guidelines of WHO. The country learnt from China the lessons of quick response and action ${ }^{35}$.

A report published as early as on April 17, 2020 in its online version of the magazine Business Insider India mentioned that both of New Zealand and Australia initiated restrictions such as nationwide lock down in conjugation with extensive testing very early. The citizens of these two countries also adhered to maintaining the social distancing and other allied guidelines spontaneously. All these helped both the countries to maintain low number of infections and deaths ${ }^{36}$.

The success of South Korea lied in the fact that the country could control the spread of the pandemic without causing stress on public health system and also on the national economy. The country had developed its capacity of mass production of test kits by early March only. By April 15 , the country could develop its capability of mass testing. In fact, by this time, South Korea was able to develop as many as 600 screening centers and 90 health care and research institutions for clinical examination of the tests conducted. The country could perform tests, which was as high as 10.4 people per one thousand populations. Jongeun You, a researcher of University of Colorado, observed that the use of information and communication technology for monitoring and rigorous contact tracing that brought success to South Korea might not be feasible in a country like the USA due to its cultural diversity. ${ }^{37}$

The analysis of the performances of some of the lowest performing nations, as found in the present study, would also validate the findings. The worst performing nation, as found in the present study, was India. A report published in The Washington Post on August 29, 2020 mentioned that India's total number of confirmed cases reached one million in five months. The number increased by next one million in twenty one days, while the same number reached third million in just sixteen days. In the mean time by fourth week of August 2020, the new cases per day reached over 77,000, the largest for any country in the world since the beginning of the pandemic. Referring to a research carried out in the University of Michigan, the newspaper also warned that
India's outbreak will soon surpass that of Brazil to remain just next to the United States in total number of $\operatorname{cases}^{38}$. The data itself were enough to serve as the testimony of India's poor performance in mitigating the pandemic.

Performance wise Brazil ranked $17^{\text {th }}$. A report published in The New York Times on 09.08.2020 observed that Brazil had recorded 100,000 deaths on August 8 itself, nearly one month ahead of the time predicted earlier by the Ministry of Health to reach the figure. The total number of cases also surpassed 300,000. The report mentioned about the government's dilemma in taking appropriate call on maintaining the social distancing. The report also noted that the new death counts per day had been over 1000 on an average since Jun $e^{39}$. The severity of the situation prevailing in Brazil could be explained with the facts that in its capital city Brasilia, nearly $80 \%$ of the ICU beds were occupied $^{40}$. Brazil's death per million counts was only next to that of Spain, Italy and the USA. The country also faced lower public confidence on government's responses. However, at least in two segments, the country showed relatively better performance. These were the number of tests per million population and in the availability of hospital beds - both are higher than countries like India. Brazil's recorded Case-Fatality Rate, however, had been lower than many countries like Canada, Germany, Iran, Italy, Spain and the UK. The highest level of stringency in government's action was around $81 \%$. The entropy generated weights showed that in case of the tests per confirmed case and the death per million population, Brazil put up abysmal performance. However, for tests per million population, Case-Fatality Rate and hospital beds per thousand population the performance of the nation was better than the worst performing ones. In case of peoples' confidence on government's actions and responses, Brazil performed poorly. Thus, mixed levels of performances across the eight criteria had just put Brazil over the three worst performing nations.

The performance score and the relative ranks of some of the other nations could also be validated in the same way. With a smaller Size of Population Singapore's performance had not been impressive. The main reason could be its inability to conduct mass tests. In fact, in case of the number of tests per confirmed case, Singapore's performance was not up to the mark. The poor performance was also observed in case of conducting tests per million population. In a paper published on June 10, 2020 online in The Online Citizen, it was mentioned that Singapore was able to con- 
duct only 7.6 tests on an average per confirmed cases ever since the pandemic outbreak occurred. The same figure stood at 18 tests in Japan, 84.9 in South Korea and 250.4 in New Zealand ${ }^{41}$.

The matter related to Ethiopia was different. The economically backward east African country lacked the essential healthcare infrastructure. Thus, testing on mass scale was not affordable. Ethiopia showed poor performance in terms of tests per million population and tests per confirmed cases. The administrators of the country admitted that the government response in terms of lock down was not possible in the already poverty stricken national economy. So, the level of stringency with which the government responded to the pandemic crisis was also low. The government depended mostly on the community based health system and on awareness created for hand washing; social distancing and putting on of the face masks etc ${ }^{42}$. As a result, though on death count, the nation had performed well, in terms of the other criteria, the performances had been on the lower side.

\section{Concluding remarks}

The study made it clear that the mitigation strategies adopted by the countries like New Zealand and Australia were not only the best, but it could also serve as the role model to combat any pandemic in future. The early government intervention in New Zealand could be well contrasted with the government dilemma in Brazil for the same cause. Singapore, a country with reasonable economic progress in its credit failed to conduct adequate number of tests. The study's most important contribution was to determine the relative importance of the criteria. The attachment of the highest importance to the population size of the countries reiterated the danger of population explosion, especially in the developing nations. The rest of the world needed to take lessons from the experiences of the better performing nations to effectively strategize the pandemic mitigation interventions followed by its execution in the best possible way.

\section{References}

1. World Health Organization (WHO). COVID-19 Strategy Update. Geneva: WHO; 2020.

2. World Health Organization (WHO). WHO global influenza preparedness plan. Geneva: WHO; 2005.

3. Ferguson N, Cummings D, Fraser C, Cajka JC, Cooley PC, Burke DS. Strategies for mitigating an influenza pandemic. Nature 2006; 442:448-452.

4. Wu JT, Leung K, Leung GM. Nowcasting and forecasting the potential domestic and international spread of the 2019-nCoV outbreak originating in Wuhan, China: A Modelling Study. Lancet 2020 395(10225):689697.

5. World Health Organization (WHO). Coronavirus disease 2019 (COVID-19) Situation Report-44. Geneva: WHO; 2020

6. Anderson RM, Heesterbeek H, Klinkenberg D, Hollingsworth TD. How will country-based mitigation measures influence the course of the COVID-19 epidemic? Lancet 2020; 395(10228):931-934.

7. Hamzelou J. WHO Expert: We need more testing to beat coronavirus [Internet]. New Scientist; 2020, [acessado 20 Ago 2020]. Disponível em: https://www.newscientist.com/article/2237544-who-expert-we-need-moretesting-to-beat-coronavirus/

8. Ethiraj G. Deaths Per Million Key Indicator of COVID Containment \& Case Management [Internet]. IndiaSpend; 2020 [acessado 22 Ago 2020]. Disponível em: https://www.indiaspend.com/deaths-per-million-keyindicator-of-covid-containment-case-management/
9. World Health Organization (WHO). Estimating mortality from COVID-19: Scientific Brief. Geneva: WHO; 2020.

10. Hasell J. What can data on testing tell us about the pandemic? [Internet]. Our World in Data; 2020 [acessado 26 Ago 2020]. Disponível em: https://ourworldindata. org/what-can-data-on-testing-tell-us-about-the-pandemic

11. Baker MG, Wilson N, Anglemyer A. Successful Elimination of COVID-19 Transmission in New Zealand. N Engl J Med 2020; 383:e56.

12. Hale T, Sam W, Anna P, Toby P, Beatriz K. Oxford COVID-19 Government Response Tracker [Internet]. Blavatnik School of Government; 2020 [acessado 28 Ago 2020]. Disponivel em: https://www.bsg.ox.ac. $\mathrm{uk} /$ research/research-projects/coronavirus-government-response-tracker

13. Center for International Cooperation (CIC). Public Opinion, Trust, and the COVID-19 Pandemic [Internet]. [acessado 28 Ago 2020]. Disponível em: https:// cic.nyu.edu/publications/public-opinion-trust-andthe-COVID-19-pandemic

14. Farhad HL, Reza F. Imprecise Shannon's Entropy and Multi Attribute Decision Making. Entropy 2010; 12;53-62.

15. Hwang CL, Yoon K. Multiple attribute decision making. Springer 1981; 58-191. 
16. Gholamreza D, Salim MF, Rosli MZ, Nazirah ZA. A hybrid approach using entropy and TOPSIS to select key drivers for a successful and sustainable lean construction implementation. Plos One 2020; 15(2):e0228746.

17. Bulgurku BK. Application of TOPSIS Technique for Financial Performance Evaluation of Technology Firms in Istanbul Stock Exchange Market. Procedia Soc Behavioral Sci 2012: 62:1033-1040.

18. Yildirim SK, Yildirim BF. The Evaluation of Competitiveness Performance for Developing Eight Countries by Grey TOPSIS. Kırklareli Üniversitesi Sosyal Bilimler Dergisi 2019; 3(2):70-79.

19. Mahmut M. Economic Performance Evaluation of European Union Countries by TOPSIS Method. North Economic Rev 2017; 1(1):83-94.

20. Kılıç M, Taşan SÖ. Performance Evaluation in Sustainability Conscious Manufacturing Companies by Using TOPSIS Method. In: Emmanouilidis C, Taisch M, Kiritsis D, organizadores. Advances in Production Management Systems, Competitive Manufacturing for Innovative Products and Services. APMS 2012. IFIP Advances in Information and Communication Technology, Vol. 397. Berlim: Springer, Heidelberg; 2013.

21. Farhad HL, Reza F. Imprecise Shannon's Entropy and Multi Attribute Decision Making. Entropy 2010; 12:53-62.

22. Shannon CE, Weaver W. The Mathematical Theory of Communication. Illinois: University of Illinois Press, Urbana; 1947.

23. Yue C. Entropy-based weights on decision makers in group decision-making setting with hybrid preference representations. Applied Soft Computing 2017; 60:737749.

24. Kaynak S, Altuntas S, Dereli T. Comparing the innovation performance of EU candidate countries: an entropy-based TOPSIS approach. Economic Research-Ekonomska Istraživanja 2017 30(1):31-54.

25. Covid-19 Data [Internet]. [acessado 28 Set 2020]. Disponível em: https://github.com/owid/COVID-19data/blob/master/public/data/owid-covid-data.xlsx

26. Max R, Hannah R, Esteban OO, Joe H. Coronavirus Pandemic (COVID-19) [Internet]. OurWorldInData.org; 2020 [acessado 28 Set 2020]. Disponível em: https://ourworldindata.org/coronavirus

27. Ourworldindata [Internet]. [acessado 28 Set 2020]. Disponível em: https://ourworldindata.org/grapher/fulllist-cumulative-total-tests-per-thousand?tab=table

28. Ourworldindata [Internet]. [acessado 28 Set 2020]. Disponível em: https://ourworldindata.org/grapher/ total-confirmed-cases-of-COVID-19-per-millionpeople?tab=table

29. Statistica.com [Internet]. [acessado 28 Set 2020]. Disponível em: https://www.statista.com/statistics/1105 914/coronavirus-death-rates-worldwide/

30. Statistica.com [Internet]. [acessado 28 Set 2020]. Disponível em: https://www.statista.com/statistics/11047 09/coronavirus-deaths-worldwide-per-million-inhabitants/

31. Statistica.com [Internet]. [acessado 28 Set 2020]. Disponível em: https://www.statista.com/statistics/1104 645/covid19-testing-rate-select-countries-world wide/

32. Dölitzsch C. Global study about COVID-19: Dalia assesses how the world ranks their governments' response to the pandemic [Internet]. Dalia; 2020 [acessado 29 Set 2020]. Disponível em: https://daliaresearch.com/ blog/dalia-assesses-how-the-world-ranks-their-governments-response-to-COVID-19/
33. World Bank Data [Internet]. [acessado 2020 Out 04]. Disponível em: https://data.worldbank.org/indicator/ SP.POP.TOTL

34. Jozi SA, Shafiee M, MoradiMajd N, Saffarian S. An integrated Shannon's Entropy-TOPSIS methodology for environmental risk assessment of Helleh protected area in Iran. Environ Monit Assess 2012; 184:69136922.

35. World Health Organization (WHO). New Zealand takes early and hard actionto tackle COVID-19. Geneva: WHO; 2020.

36. Rosie P. Australia and New Zealand have been able to keep their number of coronavirus cases low thanks to early lockdown efforts. Experts say it's probably too late for other countries to learn from them [Internet]. Business Insider India; 2020 [acessado 20 Out 2020]. Disponível em: https://www.businessinsider.in/science/ news/australia-and-new-zealand-have-been-able-tokeep-their-number-of-coronavirus-cases-low-thanksto-early-lockdown-efforts-experts-say-its-probablytoo-late-for-other-countries-to-learn-from-them-/ articleshow/75194722.cms.

37. Science News. What the rest of the world can learn from South Korea's COVID-19 response [Internet]. 2020 [acessado 29 Out 2020]. Disponível em: https://www. sciencedaily.com/releases/2020/08/200810141006.htm

38. Slater J, Masih N. India passes coronavirus milestone: The largest number of daily cases in the world [Internet]. The Washington Post; 2020 [acessado 29 Out 2020]. Disponível em: https://www.washingtonpost. com/world/asia_pacific/india-coronavirus-largest-daily-cases/2020/08/28/7cf61f0a-e7c1-11ea-bf440d31c85838a5_story.html

39. The New York Times. Brazil surpasses 100,000 virus deaths a month earlier than health officials predicted [Internet]. 2020 [acessado 30 Out 2020]. Disponível em: https://www.nytimes.com/2020/08/08/world/coronavirus-updates.html

40. The New Indian Express. Brazil makes grim COVID-19 milestone as it surpasses 1,00,000 deaths [Internet]. 2020 [acessado 30 Out 2020]. Disponível em: https:// www.newindianexpress.com/world/2020/aug/09/brazil-makes-grim-covid-19-milestone-as-it-surpasses100000-deaths-2181129.html

41. Kathleen F. Graph shows how Singapore conducts far less tests per confirmed COVID-19 case than other countries [Internet]. The Online Citizen; 2020 [acessado 10 Nov 2020]. Disponível em: https://www.onlinecitizenasia.com/2020/06/10/graph-shows-how-singaporeconducts-far-less-tests-per-confirmed-COVID-19case-than-other-countries/

42. Pilling D. No lockdown, few ventilators, but Ethiopia is beating COVID-19 [Internet]. Financial Times; 2020 [acessado 18 Nov 2020]. Disponível em: https:// www.ft.com/content/7c6327ca-a00b-11ea-b65d$489 \mathrm{c} 67 \mathrm{~b} 0 \mathrm{~d} 85 \mathrm{~d}$

Article submitted 02/09/2020

Approved 16/12/2020

Final version submitted $18 / 12 / 2020$

Chief Editors: Romeu Gomes, Antônio Augusto Moura da Silva 